\title{
The Relationship of the Green Lawrence Theory of Exclusive Assessment and Stunting Events in Busungbiu Puskesmas I Buleleng District of Bali
}

\author{
Ni Kadek Shinta Marheni \\ Magister of Health Study Program \\ of Institut Ilmu Kesehatan \\ STRADA Indonesia \\ Email: \\ $\underline{\text { shintasawitri1995@gmail.com }}$
}

\begin{abstract}
Stunting is a chronic condition that describes stunted growth due to long-term malnutrition, indicated by a TB / U z-score of less than -2 SD. Stunting data at the Pusung Busungbiu in 2019 was $51.25 \%$ so research on the factors causing stunting was needed. Method: This study was an observational analytic study with a case control approach. The total sample of 200 people included mothers and toddlers aged 24 - 59 months according to inclusion criteria. Sampling is done by using cluster random sampling to select groups of samples and simple random sampling to select samples. The independent variables of this study were maternal height, sex of the toddler, age of the toddler, family income, parent's education, mother's married age, history of maternal KEK status, history of birth weight, long history of birth, history of exclusive breastfeeding and history of time of giving MP ASI. The collected data was tested using Chi Square and multiple logistic regression to find out the significant level at the significance level $\mathrm{a}=0.05$. Results: The results of multivariate analysis showed that birth length $<48 \mathrm{~cm}$ had $(\mathrm{P}=0.00$; OR 14.1) and the age group 24-36 months had $(\mathrm{P}=0.01$; OR 1.6) while maternal height, toddler sex, family income, parent's education, mother's married age, history of maternal KEK status, history of birth weight, history of exclusive breastfeeding and history of time of giving ASI MP are not factors causing stunting. Conclusion: Birth length $<48 \mathrm{~cm}$ and age groups 24-36 months were the most dominant causes of stunting. So it is necessary to get interventions, assistance and monitoring of growth and development that is good to improve the quality of life in the future.
\end{abstract}

Keywords: Toddlers, Stunting, Risk Factors 


\section{INTRODUCTION}

Stunting is one of the nutritional problems in children under five that occurs in Indonesia. Indonesia is still in the high prevalence of stunting, data from Riskesdas in 2018 the stunting prevalence is $30.8 \%$. The impact of stunting is not only felt by individuals who experience it, but also has an impact on the wheels of the economy and nation development (Octarina et al, 2013). Stunting in children under five often occurs at the age of $24-59$ months (Rahmi CN et al, 2016). Toddler is an age group that is prone to nutrition and prone to disease, this is because toddlers are just in a transition period from baby food to adult food (Notoatmodjo, 2010). Riskesdas data (2013) in Indonesia has 15 provinces with stunting $=40 \%$ of cases, one of which is South Kalimantan which has a stunting of 43.2\%. Buleleng Regency, which is one of the districts / cities in South Kalimantan, had a stunting of 17.89\% in 2017 with the highest prevalence in the Busingbiu Puskesmas at 51.25\% (DHO Buleleng, 2017).

Stunting illustrates chronic malnutrition status during growth and development since the beginning of life which is presented with a height z-score by age (TB / U) less than -2 standard deviations (SD) based on growth standards according to WHO (WHO, 2005 ). The poor parenting style of toddler nutrition and the lack of good supervision during the 1000 HPK (first day of life) during pregnancy, breastfeeding and the child's $0-23$ months can reduce the quality of life in the future to experience stunting. The purpose of this study was to analyze the factors causing stunting in infants aged $24-59$ months in the Busungbiu regency and Buleleng Health Center in 2019. The research method used was observational analytic with a case control approach. The number of samples is 200 mothers who have children aged 24 - 59 months who are determined by cluster random sampling and simple random sampling. The cluster referred to in this study is posyandu and for respondents who fall into the inclusion criteria determined by the simple random sampling method. The independent variables in this study were maternal height, sex of the toddler, age of the toddler, family income, parental education status, mother's married age, history of maternal KEK status during pregnancy, history of birth weight, long history of birth weight, history of exclusive breastfeeding and the time history of giving ASI MP while the dependent variable is stunting.

\section{METHODS}

This research use cross sectional with sample 100 toddler (24 - 59 months) erderly by Simple Random Sampling. Independent variable (height, sex, age of toddler, family income, educational status, age of marriage, history of SEZ, history of birth weight, history of length of birth, exclusive history of breastfeeding and history of giving MP ASI) to the dependent variable (stunting) by using questionnaire in Busungbiu Village in November 2019. Data were processed and analyzed multivariate by logistic regression test.

\section{RESULTS}

\section{Description of Place of Study}

The working area of the Busungbiu I Community Health Center is in the north of the island of Bali. In the territory of 10 villages out of 15 villages in the Busungbiu District of Buleleng Regency, namely the Busungbiu Village, Pelapuan, Kekeran, Bengkel, Umajero, Kedis, Tinggarsari, Subuk, Titab, dan Telaga. (Profil Puskesmas Busungbiu, 2017).

Government health service facilities in Busungbiu District consist of 2 puskesmas, namely Busungbiu I Puskesmas in Busungbiu Village and Busungbiu II Puskesmas in Sepang Village. Busungbiu I health center is assisted by 6 sub-health centers in Kekeran, Bengkel, Umajero, Kedis, Subuk and Titab villages. Besides that, there are also 3 polindes in the villages of Umajero, Tinggarsari and Subuk. Private health care facilities consist of 1 general practice doctor and 1 dentist in the Busungbiu village and 8 practice midwives in the villages of Busungbiu, Subuk, Tinggarsari, Kekeran, Bengkel, and Umajero.

\section{Descriptive Public Data}

Descriptive Analysis of Respondents

a. Characteristics of Respondents

The presentation of the data regarding the characteristics of the respondents studied is illustrated as below: 
Table 1 Frequency Distribution of Characteristics of Children 24 - 59 months by Age and Gender at the Puskesmas Busungbiu 1

\begin{tabular}{|c|l|c|c|}
\hline No & $\begin{array}{c}\text { Toddler } \\
\text { Characteristics }\end{array}$ & Frequency & Percentage (\%) \\
\hline 1 & Age & & \\
\hline & $24-36$ & 97 & 26,5 \\
\hline & $37-48$ & 53 & 25 \\
\hline & $49-59$ & 97 & 48,5 \\
\hline 2 & Gender & & \\
\hline & Woman & 97 & 48,5 \\
\hline & Man & 103 & 51,5 \\
\hline
\end{tabular}

Almost half of toddlers who came and studied were toddlers with a range of 24-36 months of age that were 97 people (48.5\%) while 37-48 months of age were 53 people $(26.5 \%)$ and ages 49 - 59 months were 50 people ( $25 \%)$. In addition, the most sexes are 103 men (51.5\%) and 97 fewer women $(48.5 \%)$.

Table 2 Frequency Distribution of Mother Characteristics Based on Height, Race and Education in Puskesmas Busungbiu 1

\begin{tabular}{|c|l|c|c|}
\hline No & Mother Characteristics & Frequency & Percentage (\%) \\
\hline 1 & Height & & \\
\hline & $<145$ & 35 & 17,5 \\
\hline & $\geq 145$ & 165 & 82,5 \\
\hline 2 & Mother's Education & & \\
\hline & SD & 84 & 42 \\
\hline & SMP & 52 & 26 \\
\hline & SMA & 57 & 28,5 \\
\hline & PT & 7 & 3,5 \\
\hline
\end{tabular}

Based on table 2, which reviews the characteristics of mothers, almost all of the mother's height $<155$ $\mathrm{cm}$ is 162 people $(81 \%)$. Nearly half of the mothers were elementary school graduates, 84 people $(42 \%)$, 52 junior high school graduates (26\%), 57 senior high school graduates (28.5\%) and PT graduates with the least number of 7 people $(3.5 \%)$

Table 3 Frequency Distribution of Father Characteristics by Ras and Education in the Puskesmas Busungbiu 1

\begin{tabular}{|c|l|c|c|}
\hline No & Father Characteristics & Frequency & Percentage (\%) \\
\hline 1 & Education & & \\
\hline & SD & 89 & 44,5 \\
\hline & SMP & 49 & 24,5 \\
\hline & SMA & 57 & 28,5 \\
\hline & PT & 5 & 2,5 \\
\hline
\end{tabular}

In table 3 it can be seen that the characteristics of fathers in the education level category are almost half of elementary school graduates totaling 89 people (44.5\%), junior high school graduates totaling 49 people $(24.5 \%)$, high school graduates totaling 57 people $(28.5 \%)$ and graduates PT has a minimum number of 5 people $(2.5 \%)$.

Table 4 Frequency Distribution of Exclusive Breastfeeding History at the Puskesmas Busungbiu I

\begin{tabular}{|l|l|c|c|}
\hline No & \multicolumn{1}{|c|}{ Variable } & Frequency & $\begin{array}{c}\text { Percentage } \\
(\boldsymbol{\%})\end{array}$ \\
\hline 1 & Exclusive breastfeeding history & & \\
\hline & A breastfeeding history & 105 & 52,5 \\
\hline & Partial ASI & 70 & 35 \\
\hline & No exclusive breastfeeding history & 25 & 12,5 \\
\hline 2 & Reason & & \\
\hline
\end{tabular}




\begin{tabular}{|l|l|c|c|}
\hline & Mother's milk is not coming out & 21 & 22,1 \\
\hline & Sick & 6 & 6,3 \\
\hline & Work & 6 & 6,3 \\
\hline & Children cry all the time & 23 & 24,2 \\
\hline & Etc & 39 & 41,1 \\
\hline 3 & Type of Food / Beverage & & \\
\hline & Formula milk & 61 & 64,2 \\
\hline & Tea & 1 & 1,1 \\
\hline & Water & 10 & 10,5 \\
\hline & Honey & 3 & 3,2 \\
\hline & Etc & 20 & 21,1 \\
\hline
\end{tabular}

Table 4 shows that most children under five have a history of exclusive breastfeeding with 105 people (52.5\%), partial breastfeeding with 70 people (35\%) and not exclusive breastfeeding with 25 people $(12.5 \%)$. Of the 95 respondents who have a history of not exclusive breastfeeding, they have a reason because the mother's milk does not come out as many as 21 people $(22.1 \%)$, sick women 6 people $(6.3 \%)$, working mothers 6 people $(6.3 \%)$, children crying continuously 23 people $(24.2 \%)$ and other reasons with almost half of them, 39 people $(41.1 \%)$. The types of drinks mostly given were formula milk as many as 61 people $(64.2 \%)$.

Table 5 Cross Tabulation Between Descriptive Variables with Stunting Events in Toddlers Age 24 - 59 Months at the Puskesmas Busungbiu I

\begin{tabular}{|c|c|c|}
\hline Variable & Stunting & No Stunting \\
\hline \multicolumn{3}{|l|}{ Breastfeeding history } \\
\hline Exclusive breastfeeding history & $57(57 \%)$ & $48(48 \%)$ \\
\hline Breastfeeding Partial & $29(29 \%)$ & $41(41 \%)$ \\
\hline No Exclusive breastfeeding history & $14(14 \%)$ & $11(11 \%)$ \\
\hline \multicolumn{3}{|l|}{ Birth Length Status } \\
\hline$<48$ & $83(83 \%)$ & $26(26 \%)$ \\
\hline$\geq 48$ & $17(17 \%)$ & $74(74 \%)$ \\
\hline \multicolumn{3}{|l|}{ BBLR status } \\
\hline BBLR & $8(8 \%)$ & $9(9 \%)$ \\
\hline Normal & $92(92 \%)$ & $91(91 \%)$ \\
\hline \multicolumn{3}{|l|}{ Status of KEK Mothers when pregnant } \\
\hline KEK & $15(15 \%)$ & $22(22 \%)$ \\
\hline No KEK & $85(85 \%)$ & $78(78 \%)$ \\
\hline \multicolumn{3}{|l|}{ Age of married mother } \\
\hline$<18$ & $36(36 \%)$ & $29(29 \%)$ \\
\hline$\geq 18$ & $64(64 \%)$ & $71(71 \%)$ \\
\hline \multicolumn{3}{|l|}{ Mother's educational status } \\
\hline Low & $66(66 \%)$ & $70(70 \%)$ \\
\hline High & $34(34 \%)$ & $30(30 \%)$ \\
\hline \multicolumn{3}{|l|}{ Father's educational status } \\
\hline Low & $71(71 \%)$ & $69(69 \%)$ \\
\hline High & $29(29 \%)$ & $31(31 \%)$ \\
\hline \multicolumn{3}{|l|}{ Family income } \\
\hline$<$ Rp. 2.454 .671 & $80(80 \%)$ & $77(77 \%)$ \\
\hline$\geq$ Rp. 2.454.671 & $20(20 \%)$ & $23(23 \%)$ \\
\hline \multicolumn{3}{|l|}{ Toddler age } \\
\hline $24-36$ & $57(57 \%)$ & $40(40 \%)$ \\
\hline $37-48$ & $26(26 \%)$ & $27(27 \%)$ \\
\hline $49-59$ & $17(17 \%)$ & $33(33 \%)$ \\
\hline \multicolumn{3}{|l|}{ Toddler sex } \\
\hline Woman & $51(51 \%)$ & $46(46 \%)$ \\
\hline
\end{tabular}




\begin{tabular}{|c|c|c|}
\hline Variable & Stunting & No Stunting \\
\hline Men & $49(49 \%)$ & $54(54 \%)$ \\
\hline Mother's Height & & \\
\hline$<145$ & $22(22 \%)$ & $13(13 \%)$ \\
\hline$\geq 145$ & $78(78 \%)$ & $87(87 \%)$ \\
\hline
\end{tabular}

b. Bivariat Analyze

Table 6 Cross Tabulation Between Mother's Height and the Occurrence of Stunting in Toddlers Age 24 - 59 Months at the Puskesmas Busungbiu I

\begin{tabular}{|l|l|l|l|l|l|l|c|}
\hline \multirow{2}{*}{$\begin{array}{c}\text { Mother's } \\
\text { Height }\end{array}$} & \multicolumn{4}{|c|}{ Stunting } & \multicolumn{2}{c|}{ No Stunting } & \multicolumn{2}{c|}{ Total } & \multirow{2}{*}{ P value } \\
\cline { 2 - 6 } & Amount & $\%$ & Amount & $\%$ & Amount & $\%$ & \\
\hline$<145$ & 22 & 22 & 13 & 13 & 162 & 100 & \multirow{2}{*}{0,09} \\
\hline$\geq 145$ & 78 & 78 & 87 & 87 & 38 & 100 & \\
\hline
\end{tabular}

Table 7 Cross Tabulation Between Toddler Sex and Stunting Occurrence in Toddlers Age 24 - 59 Months at the Puskesmas Busungbiu I

\begin{tabular}{|l|l|l|l|l|l|l|l|}
\hline \multirow{3}{*}{ Gender } & \multicolumn{4}{|c|}{} & \multicolumn{2}{c|}{ Total } & \multirow{2}{*}{ P value } \\
\cline { 2 - 7 } & \multicolumn{2}{|c|}{ Stunting } & \multicolumn{2}{|c|}{ No Stunting } & \multicolumn{2}{|c|}{} \\
\cline { 2 - 7 } & Amount & $\%$ & Amount & $\%$ & Amount & $\%$ & \\
\hline Woman & 51 & 51 & 46 & 46 & 97 & 100 & \multirow{2}{*}{0,47} \\
\hline Men & 49 & 49 & 54 & 54 & 103 & 100 & \\
\hline
\end{tabular}

Table 8 Cross Tabulation Between Toddler Age and Stunting Incidence in Toddler Age 24 - 59 Months in Puskesmas Busungbiu I

\begin{tabular}{|l|l|l|l|l|l|l|c|}
\hline \multirow{3}{*}{ Age } & \multicolumn{4}{|c|}{} & \multicolumn{2}{c|}{ Total } & \multirow{2}{*}{ P value } \\
\cline { 2 - 7 } & \multicolumn{2}{|c|}{ Stunting } & \multicolumn{2}{c|}{ No Stunting } & \multicolumn{2}{c|}{} \\
\cline { 2 - 7 } & Amount & $\%$ & Amount & $\%$ & Amount & $\%$ & \\
\hline $24-36$ & 57 & 57 & 40 & 40 & 97 & 100 & \multirow{2}{*}{0,01} \\
\hline $37-48$ & 26 & 26 & 27 & 27 & 53 & 100 & \\
\hline $49-59$ & 17 & 17 & 33 & 33 & 103 & 100 & \\
\hline
\end{tabular}

Table 9 Cross Tabulation Between Family Income and Stunting Incidence in Toddlers Age 24 - 59 Months in the Puskesmas Busungbiu I

\begin{tabular}{|c|c|c|c|c|c|c|c|}
\hline \multirow{3}{*}{$\begin{array}{l}\text { Family } \\
\text { Income }\end{array}$} & & \multirow{2}{*}{\multicolumn{2}{|c|}{ Total }} & \multirow{3}{*}{$\begin{array}{c}\mathrm{P} \\
\text { value }\end{array}$} \\
\hline & \multicolumn{2}{|c|}{ Stunting } & \multicolumn{2}{|c|}{ No Stunting } & & & \\
\hline & Amount & $\%$ & Amount & $\%$ & Amount & $\%$ & \\
\hline $\begin{array}{l}<\mathrm{Rp} . \\
2.454 .671\end{array}$ & 80 & 80 & 77 & 77 & 157 & 100 & \\
\hline $\begin{array}{l}\geq \mathrm{Rp} . \\
2.454 .671\end{array}$ & 20 & 20 & 23 & 23 & 43 & 100 & 0,60 \\
\hline
\end{tabular}

Table 10 Cross Tabulation Between Mother's Education Status and Father's Education with Stunting Incidence in Toddlers Age 24 - 59 Months at the Puskesmas Busungbiu I

\begin{tabular}{|l|l|l|l|l|l|l|l|}
\hline \multirow{2}{*}{$\begin{array}{c}\text { Educational } \\
\text { status }\end{array}$} & \multicolumn{2}{|c|}{ Stunting } & \multicolumn{2}{c|}{ No Stunting } & \multicolumn{2}{|c|}{ Total } & \multirow{2}{*}{$\begin{array}{c}\text { P } \\
\text { value }\end{array}$} \\
\cline { 2 - 7 } & Amount & $\%$ & Amount & $\%$ & $\begin{array}{l}\text { Amoun } \\
\mathrm{t}\end{array}$ & $\%$ & \\
\hline Mother & 66 & 66 & 70 & 70 & 136 & 100 & 0,54 \\
\hline Low & 34 & 34 & 30 & 30 & 64 & 100 & \\
\hline High & \multicolumn{7}{|l|}{} \\
\hline Father
\end{tabular}




\begin{tabular}{|l|l|l|l|l|l|l|l|}
\hline Low & 71 & 71 & 69 & 69 & 140 & 100 & 0,75 \\
\cline { 1 - 7 } High & 29 & 29 & 31 & 31 & 60 & 100 & \\
\hline
\end{tabular}

Table 11 Cross Tabulation Between Age of Married Mothers with Stunting in Toddlers Age 24 - 59 Months at the Puskesmas Busungbiu I

\begin{tabular}{|l|l|l|l|l|l|l|c|}
\hline \multirow{2}{*}{$\begin{array}{c}\text { Mother Age } \\
\text { Married }\end{array}$} & \multicolumn{4}{|c|}{ Stunting } & \multicolumn{2}{c|}{ No Stunting } & \multicolumn{2}{c|}{ Total } & \multirow{2}{*}{ P value } \\
\cline { 2 - 7 } & Amount & $\%$ & Amount & $\%$ & Amount & $\%$ & \\
\hline$<18$ & 36 & 36 & 29 & 29 & 65 & 100 & \multirow{2}{*}{0,29} \\
\hline$\geq 18$ & 64 & 64 & 71 & 71 & 135 & 100 & \\
\hline
\end{tabular}

Table 12 Cross Tabulation between the Status of KEK Mothers during Pregnancy with Stunting in Toddlers Age 24 - 59 Months at the Puskesmas Busungbiu I

\begin{tabular}{|c|c|c|c|c|c|c|c|}
\hline \multirow{3}{*}{$\begin{array}{l}\text { Status of } \\
\text { KEK during } \\
\text { Pragnancy }\end{array}$} & & & & & \multirow{2}{*}{\multicolumn{2}{|c|}{ Total }} & \multirow{3}{*}{$P$ value } \\
\hline & \multicolumn{2}{|c|}{ Stunting } & \multicolumn{2}{|c|}{ No Stunting } & & & \\
\hline & Amount & $\%$ & Amount & $\%$ & Amount & $\%$ & \\
\hline KEK & 15 & 15 & 22 & 22 & 37 & $\begin{array}{l}10 \\
0\end{array}$ & \multirow{2}{*}{0,20} \\
\hline No KEK & 85 & 85 & 78 & 78 & 163 & $\begin{array}{l}10 \\
0\end{array}$ & \\
\hline
\end{tabular}

Table 13 Cross Tabulation Between Birth Weight History and Stunting Occurrence in Toddlers Age 24 - 59 Months at the Puskesmas Busungbiu I

\begin{tabular}{|l|l|l|l|l|l|l|l|}
\hline \multirow{2}{*}{$\begin{array}{c}\text { Status } \\
\text { BBLR }\end{array}$} & \multicolumn{4}{|c|}{ Stunting } & \multicolumn{2}{c|}{ No Stunting } & \multicolumn{2}{c|}{ Total } & \multirow{2}{*}{ P value } \\
\cline { 2 - 7 } & Amount & $\%$ & Amount & $\%$ & Amount & $\%$ & \\
\hline BBLR & 8 & 8 & 9 & 9 & 17 & $\begin{array}{l}10 \\
0\end{array}$ & \multirow{2}{*}{0,80} \\
\hline Normal & 92 & 92 & 91 & 91 & 183 & $\begin{array}{l}10 \\
0\end{array}$ \\
\hline
\end{tabular}

Table 14 Cross Tabulation Between Long History of Body Birth and Stunting in Toddlers Age 24 - 59 Months at the Puskesmas Busungbiu Health I

\begin{tabular}{|l|l|l|l|l|l|l|c|}
\hline \multirow{2}{*}{$\begin{array}{c}\text { Birth Length } \\
\text { Status }\end{array}$} & \multicolumn{4}{|c|}{ Stunting } & \multicolumn{2}{c|}{ No Stunting } & \multicolumn{2}{c|}{$\begin{array}{c}\text { Total } \\
\text { Stunting }\end{array}$} & \multirow{2}{*}{\begin{tabular}{c} 
P \\
\cline { 2 - 7 }
\end{tabular}} & Amount & $\%$ & Amount & $\%$ & Amount & $\%$ & value \\
\hline$<48$ & 83 & 83 & 26 & 26 & 109 & 100 & \multirow{2}{*}{0,00} \\
\hline$\geq 48$ & 17 & 17 & 74 & 74 & 91 & 100 & \\
\hline
\end{tabular}

Table 15 Cross Tabulation Between Exclusive Breastfeeding History and Stunting Incidence in Toddlers Age 24 - 59 Months at the Puskesmas Busungbiu I

\begin{tabular}{|l|l|l|l|l|l|l|}
\hline \multirow{2}{*}{$\begin{array}{l}\text { Breastfeeding } \\
\text { History }\end{array}$} & \multicolumn{3}{|c|}{ Stunting } & \multicolumn{2}{c|}{ No stunting } & \multicolumn{2}{c|}{ Total } \\
\cline { 2 - 7 } & Amount & $\%$ & Amount & $\%$ & Amount & $\%$ \\
\hline $\begin{array}{l}\text { Exclusive } \\
\text { Breastfeeding }\end{array}$ & 57 & 57 & 48 & 48 & 105 & 100 \\
\hline Partial ASI & 29 & 29 & 41 & 41 & 70 & 100 \\
\hline $\begin{array}{l}\text { No Exclusive } \\
\text { Breastfeeding }\end{array}$ & 14 & 14 & 11 & 11 & 25 & 100 \\
\hline
\end{tabular}

Table 16 Cross Tabulation Between Time History of Giving MP ASI and Stunting Occurrence in Toddlers Age 24 - 59 Months in Puskesmas Busungbiu I 
The Relationship of the Green Lawrence Theory of.....

\begin{tabular}{|c|l|l|l|l|l|l|l|}
\hline \multirow{2}{*}{$\begin{array}{c}\text { MP ASI } \\
\text { history }\end{array}$} & \multicolumn{4}{|c|}{ Stunting } & \multicolumn{2}{c|}{ Tidak stunting } & \multicolumn{2}{c|}{ Total } & \multirow{2}{*}{ Nilai P } \\
\cline { 2 - 7 } & Amount & $\%$ & Amount & $\%$ & Amount & $\%$ & \\
\hline$<6$ bulan & 72 & 72 & 64 & 64 & 136 & 100 & \multirow{2}{*}{0,22} \\
\hline$\geq 6$ bulan & 28 & 28 & 36 & 36 & 64 & 100 & \\
\hline
\end{tabular}

\section{Multivariate analyze (Ordinal Regression)}

Table 17 Results of Multivariate Analysis with Multiple Logistic Regression Test with the Backward Method

\begin{tabular}{|l|l|l|l|l|l|}
\hline \multirow{2}{*}{ Variable } & \multirow{2}{*}{ Slope } & \multirow{2}{*}{ Nilai $\mathrm{p}$} & \multirow{2}{*}{ OR } & \multicolumn{2}{c|}{$\begin{array}{c}\text { 95\% CI for Exp } \\
\text { (B) }\end{array}$} \\
\cline { 5 - 6 } & & & & Lower & Upper \\
\hline body length born & 2,648 & 0,000 & 14,130 & 6,989 & 28,565 \\
\hline Age of toddler & 0,524 & 0,015 & 1,689 & 1,106 & 2,581 \\
\hline Constant & $-4,739$ & 0,000 & & & \\
\hline
\end{tabular}

Based on table 17, the variables of birth length and toddler age significantly have an influence on the incidence of stunting. Variable history of birth length has an OR value of 14.1, which means that birth length $<48 \mathrm{~cm}$ has a risk of 14.1 times the incidence of stunting. The toddler age variable has an OR value of 1.6 which means that the 24-36 month age group has a 1.6 times risk of stunting. Between the two variables, short birth length $(<48 \mathrm{~cm})$ had the greatest influence as a cause of stunting in infants aged 24 - 59 months in the Puskesmas Busungbiu I

\section{DISCUSSION}

The results of this statistical tests show that there is no relationship between maternal height and the incidence of toddler stunting. This contradicts research in East Semarang (2012) about risk factors for stunting in toddlers aged 24-36 which shows that children born to mothers or short fathers are very at risk of becoming stunting. If one or both parents have a short body due to physical conditions (such as growth hormone deficiency) have inheritance genes in chromosomes that can carry short traits so that the child has the opportunity to inherit the gene so the child grows into stunting. If, short parents are caused by lack of nutritional needs or illness, it is likely that the child can grow to normal height as long as the child is not exposed to other risk factors (Nasikhah, 2012).

The results of statistical tests in this study indicate that there is no relationship between the sex of children under five with the incidence of stunting. The treatment of parents between toddlers, male and female genders is the same, that is, they both receive good food.

This research is also in line with the research of Izzati (2016) at Tugurejo District Public Hospital Semarang which states that there is no significant difference between the sexes and the incidence of stunting between male and female toddlers.

The results of these statistical tests indicate a relationship between toddler age and the incidence of toddler stunting. Children over the age of 24 months are four times more likely to become stunted than children under 24 months (AOR $=3.97$ [95\% CI, 1.30-12.11] (Beruk et al, 2016). By the second year there is a gradual decrease in calorie intake toddlers weight unity (Behrman et al., 1996) Because the age range of 2-3 years which tends to experience growth slowing so the chances of catching up to grow lower than the age of 0-2 years (Kusuma, 2013). According to Leroy et al (2014) at the age of 2 to 5 years increases the risk of stunting as much as $30 \%$ if there is a growth and development disorder in 1000 days of life and increases the risk of obesity and chronic diseases in the future at the age of 2-3 years who have a small birth history

Multivariate analysis test results using multiple logistic regression tests in the last step showed no relationship between family income and the incidence of stunting under five. 
This study is not in line with research conducted in Banda Aceh City by Rahayu (2019), where the level of family income is one of the factors that has a significant relationship with the incidence of stunting in infants.

The results of statistical tests in this study indicate that there is no relationship between mother's education and father's education with the incidence of toddler stunting

The results of this study are in line with research conducted by Anisa (2012) which states that mothers with low education have a risk of 10,818 times their stunting compared to mothers with higher education. In addition, research conducted by Rahayu and Khairiyati (2014) states that mothers who have low education are 5.1 times more at risk of having stunting children compared to mothers who have higher education.

The results of statistical tests in this study indicate that there is no relationship between the age of married mothers and the incidence of stunting of toddlers. This is in line with research conducted by Agustini (2016) Statistically concluded there is no relationship between maternal age with the incidence of stunting in children aged 24-59 months in the working area of Wonosari I Puskesmas and maternal age is not a risk factor for stunting, besides that the results of this study are also in line with research conducted by Astuti (2016) which states that there is no relationship between maternal age and stunting, this is because maternal age is considered to play a more psychological role as maternal factors such as the acceptance of child pregnancy so that it affects the parenting patterns children, in this case parenting giving food.

The results of these statistical tests show that there is no relationship between the history of the KEK status of the mother during pregnancy and the incidence of toddler stunting. When pregnant, the mother requires sufficient protein and complete amino acid content because during pregnancy there is an increased need for protein for fetal growth and development (Almatsier, 2006). Animal food is food that is difficult to reach for some low-income people because of the high price. The results of the study of Fitrah et al (2013) revealed that the average protein intake of subjects during pregnancy was less than 60 percent of the RDA. The quality of the protein is determined by the type and proportion of amino acids it contains. Animal protein, except gelatin, is a complete protein that contains all kinds of essential amino acids in proportions suitable for growth needs. So that even though the average KEK status of the respondent is good, if the intake of protein and other nutrients is not fulfilled, it will still have a risk of stunting.

Statistical test results in this study indicate that there is no relationship between the history of Birth Weight with the incidence of stunting of toddlers. Child birth weight in this study is grouped into two categories, namely low birth weight babies (LBW) and low birth weight (LBW). Birth weight is categorized as LBW if 0.05 ) thus it can be concluded that there is no significant relationship between birth weight and the risk of stunting in children in the Lendah II Health Center area of Kulon Progo Regency. Based on the OR (Odd Ratio) value obtained 0.544, this indicates that children with low birth weight do not have the risk of being stunted as well as children who have normal birth weight.

Multivariate analysis test results using multiple logistic regression test at the last step, the p value obtained for a long history of birth weight is 0.00 and the $p$ value for toddler age is 0.01 which indicates that there is a relationship between the long history of birth weight and toddler age with the cause stunting in toddlers aged 24 - 59 months. With an odd ratio value of 14.1 and 1.6 which means that toddlers who have a long birth history $<48 \mathrm{~cm}$ are 14.1 times more likely to experience stunting and toddlers in the age group 24-36 months more risk 1.6 times to experience stunting. Because the OR value> 1 which means a long history of birth weight and age of the toddler is a risk factor for stunting. Body length that is far below the average birth rate is due to growth retardation while in the womb. Growth retardation while still in the womb shows the lack of nutritional status and health of the mother during pregnancy, causing the child to be born with less body length (Ni'mah, 2015). Nurillah's research results (2016) showed that the length of the body born was significantly related to the growth and development of children. It was seen that children with short birth length with abnormal growth and development had a greater percentage $(66.7 \%)$ than those with normal birth length $(33.8 \%)$.

The results of the statistical test show that there is no relationship between the history of exclusive breastfeeding and the incidence of toddler stunting. The results of this research are not in line with research by Kartiningrum (2015) in his research stating that a history of exclusive breastfeeding is a risk factor for stunting in infants. Of the 20 cases used, 13 (68.4\%) were not exclusively breastfed and 
stunted. This is also the same as what researchers found where 55 people $(75 \%)$ of respondents did not exclusively breastfeed (Kartiningrum, 2015).

The results of the statistical test show that there is no relationship between the history of the ASI MP and the incidence of stunting among children. According to the results of Widyaswari's research (2011), infants who were given MP-ASI 6 months had more normal nutritional status than those aged 0-3 months or 4-5 months. Poor nutritional status in infants can be due to the introduction of MP-ASI less than 6 months. Supporting Research Results Rohmani (2010).

\section{CONCLUSION}

1. Characteristics of mothers and fathers entirely are Malay Deutro race and most have an elementary school education.

2. Most mothers of children under five have height $>145$ in the $78 \%$ case group and $87 \%$ control group and there is no relationship between maternal height and the incidence of stunting.

3. Most stunting toddlers are female at $51 \%$ and there is no relationship between sex and the incidence of stunting.

4. Most stunting toddlers are in the age range $24-36$ months which is $57 \%$ and there is a relationship between toddler age and the incidence of stunting.

5. The majority of family income is below the minimum wage, in the $80 \%$ case group and $77 \%$ control group and there is no relationship between family income and the incidence of stunting.

6. Most stunting toddlers have a father with low education that is $71 \%$ and also most of the low maternal education that is $66 \%$ and there is no relationship between father and mother education with the incidence of stunting.

7. Most age of marriage of mothers $\geq 18$ years do not have stunting toddlers as much as $71 \%$ and there is no relationship between the age of married mothers with stunting.

8. Most stunting toddlers are born by mothers who have a history of Non-SEZ by $85 \%$ and there is no relationship between the history of the status of SEZs during pregnancy with stunting.

9. Most toddlers are born with normal birth weight ie in the $92 \%$ case group while the control group is $91 \%$ and there is no relationship between birth weight history with the incidence of stunting.

10. Almost all stunting toddlers are born with a short body length of $83 \%$ and there is a relationship between the length of the body born with the incidence of stunting.

11. Most stunting toddlers get exclusive breastfeeding which is $57 \%$ and there is no relationship between the history of exclusive breastfeeding with the incidence of stunting.

12. Most stunting toddlers get breast milk MP $<6$ months which is $72 \%$ and there is no relationship between the history of breast milk MP with stunting.

13. Factors that cause stunting and have a significant relationship are toddler age and a long history of birth weight. The results of multivariate analysis, birth length $<48 \mathrm{~cm}$ and the age group of toddlers 24-36 months are at risk of causing stunting.

\section{REFERENCES}

Abdullah GI \& Ayubi D, (2013). Determinan Perilaku Pemberian Air Susu Ibu Eksklusif pada Ibu Pekerja. Jurnal Kesehatan Masyarakat Nasional, Vol. 7, No. 7.

Afifah, (2010). Faktor - Faktor yang Berperan dalam Kegagalan Praktik Pemberian ASI Eksklusif (Studi Kualitatif di Kecamatan Tembalang, Kota Semarang), tesis. FK Universitas Diponegoro Semarang, Program Studi Ilmu Kesehatan.

Afrinis N \& John T, (2011). Hubungan Persepsi dan Praktik Pemberian ASI Eksklusif dengan Statys Gizi Bayi Usia 0 - 6 Bulan. Jurnal Kebidanan STIKES Tuanku Tambusai Riau, Vol. 1, No. 1, Hal. 71-80.

Amin RM, (2011). Work Related Determinants of Breastfeeding Discontinuation Among Employed 
Mothers in Malaysia. International Breastfeeding Journal, Vol. 6, No. 4.

Arifiati N, (2017). Analisis Faktor yang Mempengaruhi Pemberian ASI Eksklusif pada Bayi. In Prosiding Seminar Nasional IKAKESMADA "Peran Tenaga Kesehatan dalam Pelaksanaan SDGs”. Fakultas Kesehatan Masyarakat Universitas Ahmad Dahlan. p. 129-135.

Astuti, I, (2013). Determinan Pemberian ASI Eksklusif pada Ibu Menyusui. Jurnal Health Quality, 4 (1) : 1-76

Azwar S, (2010). Sikap Manusia Teori dan Pengukurannya, edisi ke 2. Yogyakarta: Pustaka Pelajar.

Badan Pusat Statistik (BPS), Badan Koordinasi Keluarga Berencana Nasional (BKKBN), Departemen Kesehatan, dan Macro Internasional. 2013. Survei Demografi dan Kesehatan Indonesia 2012. Calverton, Maryland, USA: BPS and Macro Internasional.

Balitbangkes, (2010). Riset Kesehatan Dasar 2010. Jakarta: Badan Penelitian dan Pengembangan Kesehatan Kementerian Kesehatan RI.

Basrowi RW, Astrid BS, Yvan V, (2015). Benefits of A Dedicated Breastfeeding Facility and Support Program for Exclusive Breastfeeding Among Workers in Indonesia. Journal of Pediatric Gastroenterology, Hepatology and Nutrition, Vol. 18, No. 2.

Blionce AJ, (2010). The Health Benefits of Breastfeeding for Mothers. Journal of Midwifery, Vol. 6, No. 13 , p. 398-401.

Budiyanto, (2015). Hubungan Ketersediaan Fasilitas Penunjang Terhadap Keberhasilan Pemberian ASI Eksklusif pada Ibu yang Bekerja sebagai Tenaga Kesehatan. Jurnal Ilmiah Kesehatan Keperawatan, Vol 11, No. 1.

Cadwell, Turner, Maffei, (2011). Buku Saku Manajemen Laktasi. Alih Bahasa Estu Tiar. Jakarta: EGC.

Chin NP, (2010). Environmental Toxins: Physical, Social and Emotional. Journal of Breastfeeding Medicine, Vol. 5, No. 5.

Damayanti D, (2013). Asyiknya Minum ASI. Jakarta: PT Gramedia Pustaka Utama.

Destriatania S \& Fatmah, (2013). Sikap Ayah dan Jumlah Anak serta Praktik ASI Eksklusif. Jurnal Kesehatan Masyarakat Nasional, Vol. 8, No. 5.

Eliza E, (2014). Perbedaan Keberhasilan Pemberian ASI Eksklusif pada Ibu yang Mempunyai Anak Usia 7 - 24 Bulan Berdasarkan Tingkat Pendapatan, naskah publikasi. STIKES „Aisyiyah Yogyakarta, Program Studi Bidan Pendidik Jenjang DIV.

Fahriani R, (2013). Faktor yang Mempengaruhi Pemberian ASI Eksklusif pada Bayi Cukup Bulan yang Dilakukan IMD, tesis. FK Universitas Indonesia.

Fauziah L, (2014). Determinan Pemberian ASI Eksklusif pada Ibu Primipara. Jurnal Kesehatan Falatehan Banten, Vol. 1, No. 1.

Fauzie R, (2016). Pola Menyusui pada Ibu Bekerja dan Faktor - Faktor yang Mempengaruhinya, tesis. FK Universitas Indonesia. 
Firmansyah N \& Mahmudah, (2012). Pengaruh Karakteristik (Pendidikan, Pekerjaan), Pengetahuan dan Sikap Ibu Menyusui terhadap Pemberian ASI Eksklusif. Jurnal Biometrika dan Kependudukan, Vol. 1, No. 1, Hal. 62-71.

Handy F, (2015). A-Z Perawatan Bayi. Jakarta: Pustaka Grup.

Haryani, (2014). Alasan Tidak Diberikan ASI Eksklusif Oleh Ibu Bekerja di Kota Mataram Nusa Tenggara Barat, tesis. FK Universitas Udayana Denpasar, Program Studi Ilmu Kesehatan Masyarakat.

Hurlock EB, (2014). Psikologi Perkembangan, Suatu Pendekatan Sepanjang Rentang Kehidupan. Jakarta: Erlangga.

Ikatan Dokter Anak Indonesia, (2010). Indonesia Menyusui. Jakarta: Penerbit IDAI.

Ikatan Dokter Anak Indonesia, (2013). Nilai Nutrisi Air Susu Ibu. Jakarta: Penerbit IDAI.

InfoDATIN, (2014). Situasi dan Analisis ASI Eksklusif. Jakarta: Kementerian Kesehatan RI Pusat Data dan Informasi.

Kementerian Kesehatan RI, (2010). Profil Kesehatan Indonesia Tahun 2009. Jakarta: Kementerian Kesehatan RI.

Kementerian Kesehatan RI, (2015). Profil Kesehatan Indonesia Tahun 2014. Jakarta: Sekretariat Negara.

Kristianto Y \& Sulistyarini T, (2013). Faktor yang Mempengaruhi Perilaku Ibu dalam Pemberian Makanan Pendamping ASI pada Bayi Umur 6-36 bulan. Jurnal Penelitian STIKES Kediri, Vol. 6, No. 1, Hal. 99-108

Mabud NH, Mandang J, Mamuaya T, (2014). Hubungan Pengetahuan, Pendidikan, Paritas dengan Pemberian ASI Eksklusif. Jurnal Ilmiah Bidan, Vol. 2, No. 2, Hal. 51-56.

Mahmudah, (2012). Pengaruh Karakteristik (Pendidikan, Pekerjaan), Pengetahuan dan Sikap Ibu Menyusui terhadap Pemberian ASI Eksklusif di Kabupaten Tuban. Jurnal Biometrika dan Kependudukan, Volume 1 Nomor 1:62-67.

Mashuri, (2010). Penggunaan Akustika Luar-Ruangan dalam Menanggulangi Kebisingan pada Bangunan. Jurnal Smartek, Vol. 5, No. 3.

Megasari M, (2014). Panduan Belajar Asuhan Kebidanan I. Yogyakarta: Deepublish.

Neji OI, Nkemdilim CC, Ferdinand NF, (2015). Factors Influencing The Practice of Exclusive Breastfeeding Among Mothers in Tertiary Health Facility in Calabar. American Journal of Nursing Science, Vol 4, No. 1.

Notoatmodjo S, (2013). Pendidikan dan Perilaku Kesehatan. Jakarta: Rineka Cipta.

Notoatmodjo S, (2010). Metodologi Penelitian Kesehatan. Jakarta: Rineka Cipta.

Nugroho A, (2015). Strategi Jitu Memilih Metode Statistik Penelitian dengan SPSS. Yogyakarta: Andi Yogryakarta. 
Nurdiana I, (2015). Hubungan Tingkat Pengetahuan Ibu dan Ketersediaan Fasilitas Penunjang ASI Eksklusif dengan Pemberian ASI, naskah publikasi. FIK Universitas Muhammadiyah Surakarta.

Nursalam, (2010). Mengenal ASI Eksklusif. Jakarta: Trubus Agrudaya.

Nursalam, (2011). Metodologi Riset Keperawatan. Jakarta: Info Media.

Oktora R, (2013). Gambaran Pemberian ASI Eksklusif Pada Ibu Bekerja di Desa Serua Indah, Kecamatan Jombang, Tangerang Selatan. Jurnal Kesehatan Reproduksi, Vol. 4, No. 1.

Pangesti KD, (2015). Gambaran Pemberian Air Susu Ibu pada Ibu dengan Bayi Usia 6 - 12 Bulan, naskah publikasi. FIK Universitas Muhammadiyah Surakarta.

Perinasia, (2011). Bahan Bacaan Manajemen Laktasi. Jakarta: Perinasia.

Permatasari P, (2015). Gambaran Data Demografi Pemberian ASI pada Wanita Pekerja Swasta di Desa Jetis, Wilayah Kerja Puskesmas BAKI 1 Kabupaten Sukoharjo, naskah publikasi. FIK Universitas Muhammadiyah Surakarta, Program Studi Keperawatan

Prasetyono DS, (2012). Buku Pintar ASI Eksklusif. Jogjakarta: Diva Press.

Pratiwi DM, (2016). Analisis Faktor Penghambat Pemanfaatan Ruang Menyusui di Tempat Kerja Pada Pekerja Wanita di PT. Daya Manunggal. Unnes Journal of Public Health, Vol. 5, No. 2, Hlm. 100-109.

Rahmawati MD, 2010. Faktor - Faktor yang mempengaruhi Pemberian ASI Eksklusif pada Ibu Menyusui. Jurnal Kesmadaska, Vol 1, No. 1, hal. 8-17.

Riksani R, (2012). Keajaiban ASI (Air Susu Ibu). Jakarta: Dunia Sehat.

Rizkianti \& Annisa, (2014). Analisis Faktor Keberhasilan Praktik Pemberian Asi Eksklusif Di Tempat Kerja Pada Buruh Industri Tekstil Di Jakarta. Buletin Penelitian Kesehatan, Vol. 42, No. 4, hal. 237-248.

Roesli U, (2010). Mengenal ASI Eksklusif. Jakarta: Trubus Agriwidya.

Rukiyah, (2011). Asuhan Kebidanan III (Nifas). Jakarta: Trans Info Media.

Rusdjijati R \& Eko MW, (2010). Pengaruh Paparab Getaran Tempat Duduk Pengemudi Bis terhadap Kenyamanan Kerja. Jurnal Teknik Industri UNDIP, Vol. 3, No. 3.

Septiani H, Artha B, Karbito, (2017). Faktor - Faktor yang Berhubungan dengan Pemberian ASI Eksklusif oleh Ibu Menyusui yang Bekerja sebegai Tenaga Kesehatan. Jurnal Ilmu Kesehatan Aisyah, Vol. 2, No. 2, Hlm. 159-174.

SDKI, (2012). Survei Demografi dan Kesehatan Indonesia 2012. Jakarta: Kementerian Kesehatan RI.

Soekanto, (2012). Sosiologi Suatu Pengantar. Jakarta: PT. Raja Grafindo

Soetjiningsih, (2012). Buku Ajar Tumbuh Kembang Remaja dan Permasalahannya. Jakarta: Sagung Seto.

Somi MA, Subrata M, Susilo WH, (2013). Faktor - Faktor yang Berhubungan dengan Pemberian ASI Eksklusif, artikel ilmiah. STIK Sint Carolus Jakarta, Program Studi S1 Keperawatan. 
Sriningsih I, (2011). Faktor Demografi, Pengetahuan Ibu tentang Air Susu Ibu dan Pemberian ASI Eksklusif. Jurnal Kesehatan Masyarakat, Vol $6: 2$.

Sugiyono, (2011). Metode Penelitian Kuantitatif, Kualitatif dan R\&D. Bandung: Alfabeta.

Suryaningsih C, (2012). Pengaruh Demonstrasi dan Pendampingan Menyusui terhadap Motivasi dan Kemampuan Ibu dalam Pemberian ASI, tesis, FKM Universitas Indonesia.

Sutrisno AH, (2015). Ketersediaan Ruang Menyusui terhadap ASI Eksklusif pada Ibu Bekerja, naskah publikasi. STIKES „Aisyiyah Yogyakarta, Program Studi DIV Bidan Pendidik.

Tan KL, (2011). Factors Associated with Exclussive Breastfeeding Among Infants Under Six Months of Age in Peninsular Malaysia. International Breastfeeding Journal, Vol. 6, No. 2.

Tualeka AR, (2017). Metodologi Penelitian Kesehatan dan Keselamatan Kerja. Sidoarjo: CV. Bumi Lestari.

Walyani ES, (2015). Perawatan Kehamilan dan Menyusui Anak Pertama agar Bayi Lahir dan Tumbuh Sehat. Yogyakarta: Pustaka Baru Press.

Widia C, (2014). Faktor - Faktor Eksternal yang Berhubungan dengan Kegagalan Pemberian ASI Eksklusif oleh Ibu Bekerja di STIKES Bakti Tunas Husada Tasikmalaya. Jurnal Kesehatan Bakti Tunas Husada, Vol. 11, No. 1, Hlm. 14-23.

Widiyanto, (2011). Hubungan Pendidikan dan Pengetahuan Ibu tentang ASI Eksklusif dengan Sikap terhadap Pemberian ASI Eksklusif. Jurnal Kedokteran Muhammadiyah, Vol. 1 : 25-29.

Wulansari S \& Pramono MS, (2014). Hubungan Kondisi Sosial Ekonomi Keluarga dengan Pemberian ASI Eksklusif. Buletin Penelitian Sistem Kesehatan, Vol. 17, No. 1, Hal. 9-15 